\title{
National Fencing Doctrine
}

Ilya S. Fabrichnikov

Ilya S. Fabrichnikov

Council on Foreign and Defense Policy, Russia

Communication Advisor

DOI: $10.31278 / 1810-6374-2021-19-3-150-155$

The era of "Grand Alliances" seems to have come to an end. The great powers (Russia certainly being one of them) are revisiting

their obligations to client states and "junior partners" in realtime mode, focusing on internal processes and obligations to their citizens. The Russian National Security Strategy 2021 is no exception in this respect.

On July 2, Vladimir Putin signed Presidential Decree \#400, putting a new National Security Strategy into effect. It replaced a similar document adopted in 2015, which, in turn, revoked the National Security Strategy until 2020, signed by then President Dmitry Medvedev during his first year in office. A quick glance at the document clearly shows what a long way the Russian foreign policy thinking has gone or rather raced-by historical standards. In a mere six years (from 2009 to 2015), Russia made a U-turn (from declaring partnerships to acknowledging confrontations), which is now cemented in the new Strategy.

In terms of risk assessment, the Strategy is a comprehensive and detailed document. And, perhaps, if it were thoughtfully studied by the foreign policy establishments of other countries, it would be possible to avoid unnecessary aggravations over the "red lines" which are so crucial for the Russian leadership and which are clearly outlined in the Strategy. 
Medvedev's Strategy presented Moscow's view on the multipolarity of the world order and defined it as a foundation for strengthening Russia's international influence. The named threats included only "the likely recurrence of one-sided reliance on the use of force in international relations, disagreements between the key actors in world politics, the threat of proliferation of weapons of mass destruction and their use by terrorists, and more sophisticated forms of unlawful activity in the cybernetic and biological domains, as well as in the field of high technology," and the growing "threat to the stability of industrialized and developing countries, their socioeconomic development and democratic institutions" (Section II, Article 10).

In general, the Strategy demonstrated a rather amicable attitude towards foreign partners (the U.S. and the EU), but described in detail regional sources of possible national and global security threats: Iraq, Afghanistan, and the Korean Peninsula. In principle, Russia considered itself incorporated into the international agenda and spoke about cooperation with the United States in about the same areas that are discussed today - transparency and strategic stability. Moreover, Russia planned to build an integrated economic space with the EU (Section II, Article 16).

But the good intention to develop relations with the United States and the European Union was almost completely gone in the "updated" Strategy 2015. The document stated quite firmly: "The U.S. and EU support for the anti-constitutional coup in Ukraine led to a deep split in Ukrainian society and to an armed conflict. The consolidation of the extreme right-wing nationalist ideology, the intentional portraying of Russia as an enemy of the Ukrainian people, an undisguised emphasis on the forceful resolution of internal contradictions, and a deep socioeconomic crisis are turning Ukraine into a long-term hotbed of instability in Europe next to the Russian borders." At the same time, Russia continued to call for "strengthening mutually beneficial cooperation with European states and the European Union, harmonizing integration processes in Europe and the post-Soviet space, and building a transparent collective security system in the Euro- 
Atlantic region on a clear legal and contractual basis" (Article 97 of the updated version of the Strategy 2015).

The new document avoids substantive language completely as if some world actors have suddenly disappeared. The key foreign policy doctrinal document now refers to a homogenous "West."

The new Strategy bluntly states: "The desire of Western countries to maintain their hegemony, the crisis of modern models and instruments of economic development, increasing disproportions in the development of nations, growing social inequality, and attempts of transnational corporations to limit the role of states are accompanied by aggravating domestic political problems, deepening interstate contradictions, declining influence of international institutions, and decreasing effectiveness of the global security system." The Strategy refers to "some countries" as a source of threats, without specifying them.

Even the "post-Crimean" Strategy 2015 stated that "the Russian Federation is interested in building a full-fledged partnership with the United States of America on the basis of intersecting interests, including in the economic field, taking into account the key influence of Russian-American relations on the international situation as a whole." The Strategy 2021 has no trace of such intentions.

Foreign policy partnerships have been revised as well. While the Strategy 2015 (contrary to the 2009 document) emphasized Russia's intention to develop the partnership with China and, separately, a privileged relationship (in these particular terms) with India (Article 88, 93, and 94, respectively), the current document lists these countries one after another (Article 101, subsections 7 and 8, respectively). The constantly fading role of the Commonwealth of Independent States in Russia's foreign policy rhetoric is also noteworthy. While the Strategy 2009 (Article 13) stated that the CIS was a priority for Russian foreign policy, and the 2015 edition still named the CIS as "one of the key areas" (Article 89 of the updated version), Strategy 2021 lacks the CIS focus altogether, it just briefly names it in abovementioned Article 101, subparagraph 5 in the context of the tasks for achieving Russia's foreign policy goals.

The evolution of Russia's national interests, cited in all three versions of the Strategy, is of particular interest. For example, 
in 2009, only three key Russian national interests were stated: 1) the development of democracy, civil society and economic competitiveness; 2) the inviolability of the constitutional system; and 3) the transformation of the Russian Federation into a world power, whose activities are aimed at maintaining strategic stability and mutually beneficial partnerships in a multipolar world. In 2015, six points were listed: 1) strengthening the country's defense to ensure the inviolability of the constitutional system, sovereignty, independence, state and territorial integrity of the Russian Federation; 2) strengthening national harmony, political and social stability, developing democratic institutions, improving mechanisms of interaction between the state and civil society; 3 ) improving the quality of life and people's health, ensuring stable demographic development of the country; 4) preserving and developing culture, and traditional Russian spiritual and moral values; 5) increasing the competitiveness of the national economy; and 6) securing Russia's status as one of the leading world powers, whose activities are aimed at maintaining strategic stability and mutually beneficial partnerships in a polycentric world.

In 2021, there are already eight clearly identified national interests. These are 1) preserving the population of Russia, developing human potential, improving the quality of life and well-being of citizens; 2) protecting the constitutional order, sovereignty, independence, state and territorial integrity, enhancing defense capabilities; 3) maintaining peace and harmony in the country, strengthening the rule of law, eradicating corruption, protecting citizens and all forms of property from unlawful attacks, developing mechanisms for dialogue between the state and civil society; 4) developing a safe information space, protecting Russian society from destructive information and psychological influence; 5) ensuring sustainable development of the Russian economy on a new technological basis; 6) protecting the environment, conserving natural resources and ensuring their rational use, adapting to climate change; 7) strengthening traditional Russian spiritual and moral values, preserving the cultural and historical heritage of the people of Russia; and 8) maintaining 
strategic stability, strengthening peace and security, and legal foundations of international relations.

The shift to internal affairs is obvious (it is worth noting that the approach to domestic policy and the development of society is described in a purely conservative, protective way, but that is a subject for a separate analysis).

While in 2009 two of the three national interests were directed outward, and in 2015, two out of six, today there is only one such point-maintaining global strategic stability.

Russia has no other common points with the international security system (it must be said that such points disappeared in other world powers' strategies even earlier). Given the declining quality of external strategic partnerships, we can say that the National Security Strategy has voluntarily lost its "multi-vector" and "polycentric" character declared for almost twelve years. Even the "central and coordinating" role of the UN and its Security Council, which were always stated in the previous versions of the Strategy (and is still stated in the new one) is now counterbalanced by an assertion that "the formation of a new architecture, rules and principles of the world order is accompanied by the emergence of not only new challenges and threats, but also additional opportunities for the Russian Federation" (Article 23 of the 2021 Strategy). In other words, the UN is the UN, of course, but a new architecture is a new architecture.

Is there any reason to regret that the Russian Federation has stopped, at least at the doctrinal level, investing in the declaration of its own alliances or foreign policy priorities? Scarcely. The way the system of international relations is evolving today, and the value which traditional hegemons and their client states assign to second-tier alliances clearly characterize the current state of international relations: any union and any agreement can be revised under deteriorating external and internal circumstances.

Is the U.S. tired of the war in Afghanistan? Its troops were withdrawn from that country within a few months. Are the French units experiencing excessive pressure in the Sahara-Sahel zone? They are being pulled out without any regard for the agreements 
with traditional African allies and partners. Do European countries consider their obligations fulfilled? NATO European contingents left Afghanistan even faster than the Americans.

The era of "Grand Alliances" seems to have come to an end. The great powers (Russia certainly being one of them) are revisiting their commitments to client states and "junior partners" in real-time mode, focusing on internal processes and obligations to their citizens.

The Russian National Security Strategy 2021 is no exception in this respect. It underlines the current state of affairs in international relations from the point of view of Russia's federal government and security agencies-the military, intelligence and counterintelligence services, and the presidential administration.

Phrases like "increasing the mobilization readiness of the Russian Federation and the readiness of civil defense capabilities" (Article 40 of the new Strategy) or "creating strategic reserves of mineral resources sufficient to guarantee the mobilization needs of the Russian Federation and the needs of the country's economy in the long term" (Article 67, subparagraph 34 of the new Strategy) may worry ordinary people, but it seems that we will have to get used to this zeitgeist.

Overall, the National Security Strategy 2021 has a pronounced internal and, most importantly, mobilization character. For the first time in many years, it clearly states that Russia should rely primarily on its own resources rather than on international cooperation or multivector allied or partnership commitments, which may not work in a rapidly changing environment.

Surprisingly, presidential documents concerning the National Security Strategy have not yet been comprehensively studied and thoroughly analyzed by foreign policy experts abroad, especially in terms of their evolution. By assessing the strategies adopted in 2009, 2015 , and 2021, one can see how the perception of key national security threats by the Russian leadership has changed, and, accordingly, how the world has changed (so profoundly) in a historically very short time. 